Savunma Bilimleri Dergisi

The Journal of Defense Sciences

Kasim / November 2021, Say1/Issue 40.

ISSN (Bas1l1) : 1303-6831 ISSN (Online): 2148-1776

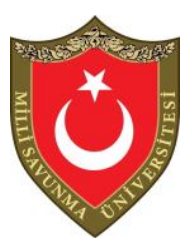

\title{
Religiously Motivated Terror Discourse (Daesh Case)*
}

\author{
Oktay KİRAZOLUĞU**
}

\begin{abstract}
Although Daesh has lost its effect physically, its influence on manpower remains a matter of curiosity. The aim of this article is to define 'Religiously Motivated Terror Discourse' on Daesh terror organization case. Daesh's online magazines, Dabiq and Rumiyah, are analyzed by content, thematic and discourse analysis. The analysis displays that Daesh constructs its discourse on the main themes (manhaj, jihad, tawhid, jama'ah, hijrah, imamah, ummah, khalifah) which prefigure and integrate each other. Themes are linked to form a cause and consequence cycle in the construction of this discourse. Fictitious description of events, ideological separation in narratives, binary opposing themes in propositions, absence of gray zone in narratives, divine narratives, brutal imagery in visuals, discourse on the vengeance of humiliation, the motivation of group members, and use of inner group jargon are the main characteristics of this discourse.
\end{abstract}

Keywords: Discourse, Narrative, Terror, Daesh.

\section{Dini Motifli Terör Söylemi (Deaş Örneği)}

$\ddot{O} z$

Her ne kadar fiziki olarak etkisini yitirse de, Deaş terör örgütünün insangücü üzerindeki etkisi merak konusu olmaya devam etmektedir. Bu çerçevede yapılan çalışmada, Dini Motifli Terör Söylemi'nin Deaş terör örgütü örneğinde tanımlanması amaçlanmıştır. Araştırmada, Deaş'ın çıkarmış olduğu Dabık ve Roma dergileri içerik, tema ve söylem analizi tekniği ile incelenmistir. Sonuç olarak; Deaş'ın söylemini birbirini şekillendiren ve bütünleştiren temalar üzerine

* This article is produced from $\mathrm{PhD}$. thesis of the writer.

** PhD., Col., MoD, email: kirazolugu@ yahoo.com, ORCID: 0000-0002-9036-6019

Geliş Tarihi/Received : 21.09.2020

Kabul Tarihi/Accepted : 04.08.2021

Araştırma Makalesi/Research Article

DOI: $10.17134 /$ khosbd.1001188 
kurduğu, söylemin oluşumundaki temaların (hakikat arayışı, kutsal savaş, birlik, topluluk, göç, devlet başkanı, Müslüman toplum, yönetim) bir sebep ve sonuç döngüsü içerisinde birbirine bağlantılı olduğu görülmüstür. Olayların kurgusal tasviri, anlatılarda ideolojik ayrılık ve gri bölgenin bulunmaması, önermelerde ikili karşıtllklar, ilahi anlatım, şiddetin görselleştirilmesi, aşă̆llanmaya ilişskin intikam söylemi, grup üyelerinin motivasyonu ve grup içi jargonunun kullanımına yönelik temalar dini motifli terör söyleminin temel özelliklerini oluşturmaktadır.

Anahtar Kelimeler: Söylem, Anlatı, Terör, Deaş.

\section{Introduction}

The term 'pseudo-state' might be a proper description for Daesh regarding its organization, assets, and actions, which display almost all aspects of a state until recently. Nowadays, this terror group is literally said to be on the brink of its end, but during its peak period, the efficiency of its media capability via its online publications had a considerable effect on its members and followers. Apart from its political and military organization, Daesh utilized online media apparatuses to influence its target audience. The consistency of its narratives and discourse is of utmost importance in these media apparatuses to affect the audience, to easily recruit members in its ranks, and to gain an advantage over the other competing actors in the region. Daesh has utilized religiously motivated terror discourse as a means of communication. Terror discourse is a specific kind of narrative in communication literature, but religiously motivated terror has different motivation foundations and discursive methods, which should be clarified and analyzed in practical terms to struggle with. Governments have not been experienced in encountering its narrative with persuasive arguments to lessen its magnetism. At the central of its narrative, familiar themes are processed for most of the Muslims. Within this context, the online magazines of Daesh give essential clues about the usage of language and its discourse in order to challenge and undermine it.

\section{Theoretical Framework}

Terrorism relies heavily on press coverage and modern communication channels. The so-called "symbiosis" between terrorists and the news media is a critical theme of media-terrorism research and practice. Particularly some researchers claim that there would be no terrorism if the media did not convey their messages. According to Schmid and de Graaf (1982: 15), terrorists' acts should be 
viewed as "violent language", which functions as propaganda. The result is behavior modification of the target audience by both coercive and persuasive means. In practical use, terrorism practices violence against an object to acquire an effect upon other objects. The immediate victims are merely an instrument or tool of communication.

According to Kellner (2006: 41), governments and terrorist organizations have deployed spectacles of terror to promote their political agendas; by creating Manichean (duality) discourses of good and evil, which themselves fit into dominant media codes of absolutist discourses. During the 80's there is a continuous effort to remind 'Islam' and 'terrorism' words by using them in pairs. West is forming an antagonism by this discourse through describing it with molded judgments. In fact, military interventions are strived to be justified by the prearranged news frames and discourses. This instigated two reactions; 'unconditional approval' and 'radical denial'. Radical denial broadens its opposition area by the revolt given shape under socialist, nationalist, and religious ideologies (Aydınalp, 2011: 298). Religiously motivated terror phenomenon should be seen as a part of this opposition zone. Radicals comprehend it as a religious obligation to resort to political power for putting their ideological systems into practice and imposing it on all society. These are the call of the traditional Salafi movement to a form of pure and credulous Islam; besides, it has been regarded as a religious duty to struggle against other groups with this ideological basis (Zeidan, 2003: 43). The discourse of Islamist radicalism constitutes a formation of Islamic society reflecting the environmental conditions of the $7^{\text {th }}$-century Arabic peninsula. Thus, all kinds of governments are seen as illegitimate, which became a religious mandate to struggle in the notion of jihad (Diamond, 2003: 285). Accordingly, militant movements that establish an Islamic state represents 'darü'1-Islam'. Contrary to this phenomenon, the rest of the world represents 'darü'l-harp', which justifies all the offenses (Bennett, 2004: 38). Although each violent religious group is a model within its historical and cultural conditions, it has distinctive features in terms of the value they attribute to religion in society. As has been in Christianity, Judaism, Islam, Buddhism, Hinduism, or Sikhism, violent religious groups strongly oppose the harmony and reconciliation of traditional religious structure. It rejects the boundaries drawn by the secular religious conception that individualizes the religion out of the public sphere. They seek to create a new form of religiosity by a 
conflict, which ultimately points to a worldview and feeds a sense of belonging. It is the hope of victory, which makes the war under fundamentalism more reasonable than the hopes of peace. In this sense, religion may be the engine of religious violence by providing a world view, motivation, organization, and legitimization (Juergensmeyer, 2000: 4). However, the relation of religion with violence cannot be actually understood without political, social, and ideological context. Religion individually does not lead to direct violence, and allegedly religious violence is shaped by factors other than religion.

The internet amplifies and facilitates dynamics of radicalization into violent extremism, accelerates catalysts for engaging in radicalizing cognitive processes, and eases access to radical discourses (Beadle, 2017: 2). Over the last decade as a terror group, Daesh's media strategies are more contemporary and wide-reaching than its predecessor Al Qaeda's. Daesh has been using emotions in internet jargon (net-speak), which is a mobilizing factor in collective action literature to connect with young individuals (Vergani \& Bliuc, 2015: 7). Modern government supported counter-narrative efforts are mainly insufficient in subduing the extremist ideology. Accordingly, restriction and exclusion of the content are impractical. There is a growing need to address the background of radicalization caused by the ideological charm, and it is vital to find positive alternatives for the extremist narratives to struggle (Liang, 2015: 1). Controlling the narrative rather than gaining territorial control, countering West, Shia Muslims, and rival jihadist factions and regime, contrasting themselves with other jihadist factions, projecting themselves more powerful than they presently are, connecting supporters in on-line networks, recruiting new members, intimidating and deterring opponents, demonstrating capabilities and raising funds are the main aspects in its media strategy (Nissen, 2014: 2). Positive narrative and counter-speech as messaging apparatuses are other strategies. Religious, ideological, and emotional capabilities allowed Daesh to take place in the collective perception (Winter, 2015: 6). It created news frames that serve the interests of a consistent brand with a dual message system that resonates with cultural values (Melki \& Jabado, 2016: 101). Metaphors are also used in the narratives as main channels for categorizing how they perceive in-group members and outside groups (Olufowote \& Matusitz, 2016: 16). The majority of propaganda products are about providing governance, justice, and new construction. Narratives highlight the misconducts of the enemy and the 
good deeds of Daesh. There is huge exertion on enlisting talented users on social media for the continuation of the recruitment (Gates \& Podder, 2015: 109). According to Winter (2015: 6-7), Daesh's propaganda alone is not the reason why someone becomes a supporter. What propaganda does is to catalyze the individual's radicalization and distillate their already-held sympathies.

\section{Analysis of the Magazines}

An effort to answer the questions: "What are the significant themes used in Daesh's publications? And what are the characteristics of the discourse used by Daesh?" should help to outline the aim of this descriptive analysis. Accordingly, a revised version of Van Dijk's discourse analysis methodology (1988: 9-38; 2007: 170) is used to frame the study under the topics of thematic structure, entries, photographs, schematic structure, syntactic analysis, local coherence, lexical style, rhetoric, and effectiveness. The research sample comprises of Daesh's all episodes of Dabıq (15) and Rumiyah (10) online Magazines issued between the years 2014 and 2017. "Atlas.ti" software is used to determine the themes, frequency, and schematic structure of the narratives.

\section{a. Thematic Structure}

Literature review displays a few results concerning the narrative of Daesh and its themes in its publications. According to Cosgrave and et al. (2014: 101), Daesh has a narrative depending on some main themes. These are the history of lost glory, injustice, humiliation, failed governance, an ongoing civil war, leading to Muslims, a promise to purifying Islam, conquering enemies, organization's brutal and opportunistic rise. Pellerin (2016: 8) emphasized six themes on the terror group's recruitment process: a direct call to jihad, religion, honoring dead fighters, communication to Muslims, and defamation (in-out grouping). But Fernandez (2015: 11) defined the narrated themes as; urgency (Muslims are being slaughtered), agency (do something now to save the Muslims), authenticity (join the organization), victory (here to stay and grow), which were transmitted through decentralized broadcast centers. As for Zelin (2015: 85), military affairs, governance, preaching, moral policing are some of the themes which rely heavily on visual as opposed to text-based propaganda. Daesh tells not only what we already know but also what we want to hear. Specifically, "the clash of civilizations" narrative covers enough space to gratify the feeling of revenge. It 
uses this modifier just as often as any news report or academic article (Semati \& Szpunar, 2018: 6). Daesh strives to portray legitimacy in politics and religion and uses Islamic scripture as a tool, portraying itself as a cause for righteousness against a world inhabited by nonbelievers and apostates who need theological correction (Greene, 2015: 50-51).

In light of the review, magazine issues have been uploaded in the analysis software (Atlas.ti) to find out the most used words by word clouding. The clusters of these words have been analyzed qualitatively in terms of which themes have been formed in the narratives. Eight themes are outlined as the main themes of the narratives, which primarily come from the Islamic literature. Manhaj (truthseeking) is obligatory advice for the members to find out the right path within the limits of the references. Daesh frames "seek of truth" in its own terms, particularly before and after joining the ranks. Tawhid (unity) clarifies the sole tenet and path for the unification of the followers. It is a basis for the Salafi Jihadists, who rejects all the other interpretations of Islam. Jamaah (community) is the form of communal to become a respected power. The group is a vital institution in which the member clarifies and confirms his/her ideological background. Jihad (holy war) is an order for the members and a tool for achieving the aims. Without this obligation, terror actions cannot be executed or achieved in a fearless mood. Hijrah (migration) is a compulsory replacement for the members in order to join the ranks of Daesh in the appreciated place. Genuine Hijrah is a historical event during the Prophet's era which progressed as a result of the enforced circumstances. Imamah (head of governance) is the leader of Daesh whose authority is heavenly. Customarily, there should not be an Imam or his successor except the historical ones according to the quotes. Ummah (Muslim community) corresponds to the Muslim community as a whole, and Khalifah (governance) is the state of forming the necessities of Islamic governance. These themes already carry definite meanings and interpretations, but Daesh redesigned them to form a unique and effective message for the audience and display a desire on the romantic image of the renewal of a historical empire. It also creates an image of a new caliphate constructed on a holy war. The name of the magazine, Dabiq, is a place in Syria that is supposed to be the scene for one of the final battles according to main religion myths about the Armageddon. Daesh's intention in selecting the name for the magazine has a signifying purpose. It is a metaphor for the expected end of the world according to a hadith. The early issues 
of the magazine concentrate on the importance of the declaration and meaning of the Caliphate. Practically, the victories have been favored and boasted of convincing more people to join the group. Main themes "Imamah, Khilafah, Jihad, Hijrah, Ummah" are defined in connection with another and form the ideological basis of the group. "Hijrah" has been given utmost importance for the recruitment policy since the manpower resources rely heavily on attracting men and women outside the region. As an antagonism, "hypocrisy", the opposite of "sincerity", is widely used in the narratives. The "enemy" is metaphorically identified as "America", "crusader" or "Romans" by citing the historical crusaders. Internal jihadi disputes are also handled with the opposing themes. Al Qaeda is a "tandhim" (organization) as opposed to Daesh, which is a "dawla" (state) in its own terms. The narrator put the emphasis on "tandhim" to load an opposite meaning with an aim to oust other terror groups. The words "kufr" and "scholars" are used to emphasize binary themes in the context of justifying its ideology and falsifying the thoughts of the mentioned scholars. Particularly, "nusayri, rafidah, safawi, sahwah" are widely used in Shia interpretation. The narration usually continues to reject all kinds of differentiation from their construal of religion. "Rafidah" is a derogatory term for Shia while "Dajjal" is an antichrist figure in Muslim eschatology. Themes "jihad, khilafah, bayah" are expressed as opposed to "crusader, factions, PKK, tawaghit", in which we can observe the antagonism in the narration. The term "Shariah" is used by the narrator to maintain the legal aspects of society. The narrator reiterates the ideological division of the world into two camps between Islam and the others. In fact, contradictory themes, "muslim, brother, us, mujahid" and "crusader, kuffar, evil, hypocrites" support the "clash of civilizations" discourse. The verbs "jihad, fight, follow, kill" have strong meanings and supportive effects on the reader beyond their representative structure. Binary opposing themes recurred as "us / west", "mucahiddin / crusaders", "khilafah / allies", "leadership / tawaghit", "shariah / rules", "mucahid / apostate" or as "Christianity / Islam" that are widely used in the narrative of magazines.

The thematic structure is applied especially on the headlines of the articles. Active usage of the sentences is more common when compared to passive sentences in the propositions. The passive voice is used in formal documents where an action or condition is considered more important than who did it. Some articles contain passive usages to emphasize the event or the action; nevertheless active 
voice is commonly preferred to stress on the subjects rather than the action. The importance of the words in the headlines is selected according to the plot of the narrative. Historical themes are used and stressed in the headlines commonly for the justification of the assertions. Some of the headlines have mockery with the related aspect in order to attract the attention of the reader. The ridiculed themes are enemized by descriptive definitions with citing to historical context. The narrator basically applied the macro rules to reduce information which is made by deletion, generalization, and reconstruction. Generalization has been applied to form a unique meaning, and topics assure the narrative has a semantic unity.

\section{b. Entries}

While the initial issues of Dabiq have spectacular entries ornated with visual backgrounds, the following episodes rather have more detailed entries. Generally, a brief explanation is made to clarify the context or to acknowledge the reader immediately after the headlines. Parts of entries comprise phrases of historical figures in Islamic history, hadiths, or verses to justify the assertions which will be proclaimed in the text. Most entries give important clues for the rest of the narrative. Some have no abridgment and condensation of the plot, for which an entry part should include for the sake of comprehension. Nevertheless, the entries apply the similar rules of an article, news, or an interview as a construction material of the narrative.

\section{c. Photographs}

Several visuals are analyzed by semiotics in the context of its narrative. Horrific and brutal photographs have been excluded as they may not serve the purpose of this study. However, it is hard to simplify on specific occasions of a particular visual; the mutual aspects are drawn as a conclusion. The relations between the sign, signifier, and the signified confirm the theoretical assertions of Saussure. Photographs and visuals in the magazine have exaggeration when compared to usual instantaneous ones to emphasize the signified in the context. The narrator strengthens his view by visuals, even if these might seem ridiculous. Some of the photos needed explanation to turn out a strong influencer for the target audience. The identification of the group members is symbolized with heroic postures in the photographs, which are in line with the narrative. The usage of context detached photos in narratives is more than enough. Most of them have 
utilized Islamic motifs, which may be in parallel with the reader's mental construction. Praying and worshipping scenes reflect a strong message to the members as their main strength comes from the religious practices. Most of the visuals are decorated with guns and ammunitions which reflect the realization of the war aspect. The photographs of Daesh leader have been specifically worked on in positioning and the demonstration of body language. The signification is revealed in the symbolism of the Wahhabi-Salafi trend, which Daesh heritages its ideological stance. From the flag of Daesh to the uniforms or the usage of colors and body postures have been utilized as a signifier in a setup by the professionals with an intention to induce the audience, which is a part of the propagative process. Photographs represent a certain period of time by freezing it; thus, the viewer can look at the photograph profoundly. Photographs affect the discourse which is preferred by the press in presenting war on how the society perceives it. Some of the photos used in Dabiq have a purpose of showing the effort or 'quid pro quo' of the struggle. As Zelizer (1995: 136) iterated, war photographs were accompanied by text labeling of the scene despite the real facts. Photo and narration have a symbiotic relationship so as to underpin the objective reality of each other. Thus, the usage of the photo has a propagandist approach accompanying its narrative. The narration mainly supports the visualization, and vice versa is also valid. The connotational meaning of the photos mainly signifies Daesh members' persistency in struggling with the enemy. According to Barthes (1968), no sign may have a meaning apart from the entire scheme. The signified and signifiers should be thought of, as parts of a social construction. Most of the visuals are used to signify the heroic aspects of the Daesh members and their success on the battlefield, which is a strong argument as a propagative instrument, whereas some of them have a purpose of undermining opponents' powerful aspects and parlay the discourse of weaknesses. Some visuals signify the everyday life of the group, which demonstrates itself as a steadfast state by setting forward the acquisitions such as accommodation, occupations, or currency so the sympathizers should emigrate. 


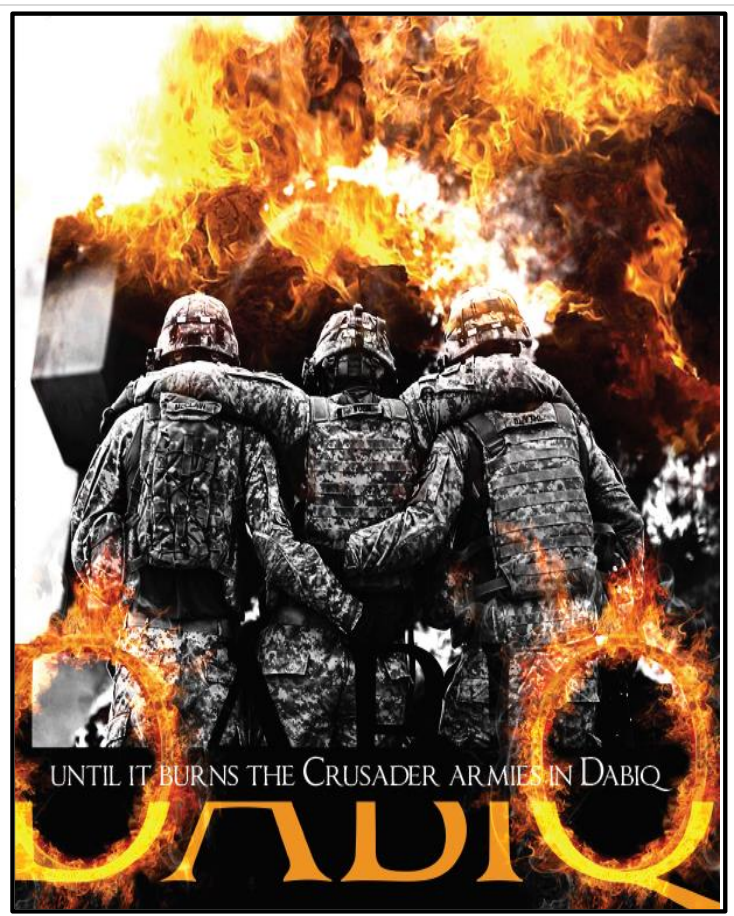

Figure 1. Cover Page of Dabiq (2015, $1^{\text {st }}$ Issue).

\section{d. Schematic Structure}

Selected narratives have been coded under the structures and propositions in order to show their schemata are in line with the schemata put forward by Van Dijk (1988: 51). Accordingly, the schema of the narratives has common similarities. Headlines, sub-headlines, and entry parts represent the top superstructure category. Macrostructure categories are comprised of event, context, circumstance, consequence, and evaluation parts. Propositions are mapped in an ordered sequence of sentences. Each superstructure category is filled with a macro proposition. 


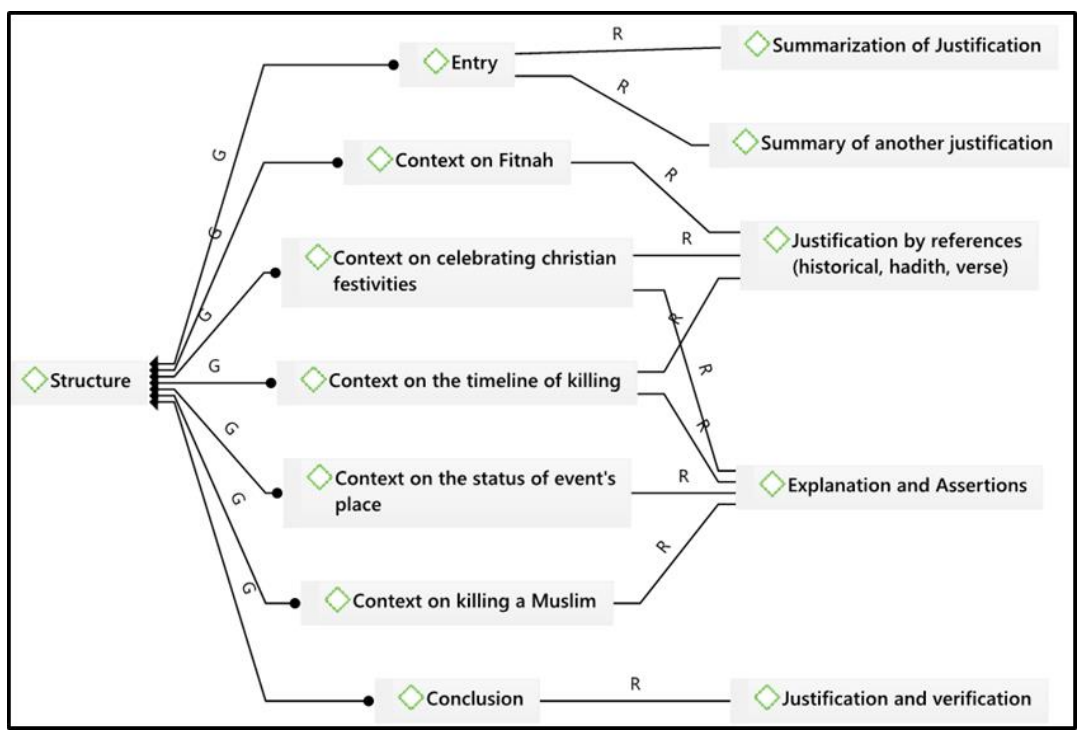

Figure 2. A Sample Schemata of a Narrative in Rumiyah "G: part of / R: associated with" (Kirazoluğu, 2020: 167).

Particularly, an event or context is defined in the entry part, then circumstance or context info is defined. The context or consequence part is supported by verses or hadiths for the justification of the assertions. Hadiths and verses have been deliberately cited to legitimize the contexts. Most consequential narratives support the themes. The events and the consequences are evaluated in the narrative in a poetic manner. Evaluation and objectives cover the future expectations, therefore; the apocalyptic and unearthly objectives lure the group's potential recruits for the future. Some of the narratives are independent of the predecessor with an intention to up bring many topics as possible as it can. Propositions, verses, and invocations are used to compose the themes. Although the narrative on circumstance is relatively weak, the structure is meticulously designed, and the propositions are used in order. Cross-examinations are widely used, in which the narrator justifies the questions with eligible answers. Some of the narratives are given in a news format to make them more credible. A justification part with the main mottos of Daesh in the end is used in some of the narratives to reinforce the plot. The cause and effect cycle are used in every means in the storyline, which is justified by the historical context. It can be generally assessed from the schemata that the structure of the narrative is meticulously designed, the 
context for the events are used in order, assertions supporting the themes are organized, and the justifications of assertions are satisfying for an average level reader. Nevertheless when closely examined; the events and quotes are selected on purpose to build up the narrative, historical events are not mainly related with the assertions, the assertions do not necessarily contain adequate logical coherence, and the justifications solely rest on religious sources and historical analogies.

\section{e. Syntactic Analysis}

Phrases, clauses, and sentence forms are analyzed in order to distinguish between its meaning and expression. Local semantics deals with the propositions, and most sentences in ordinary language use propositions, which may sometimes be in complex structures. The propositions used in narratives bring the reader to an assertion regarding a more comprehensive outcome. This assertion gives the reader preliminary information for the rest of the story in advance for his mental formations. The leading sentences in the articles summarize most of the story, which is in line with usual syntactic structure. Most structures form a cause and consequence form in between the propositions. A common proposition type used in a narrative is an explanatory one which summarizes the plot and explains it in an epical style. Besides, descriptive propositions are used by combining irrelevant assertions without a need to prove them. The proposition types used in the sections of the articles vary according to the objective it was used. Comparison is widely used to make an analogy in between the timeline. This syllogism is particularly used during the explanation of negative events for clarification. A conclusion is always drawn from the assumed propositions which try to approximate the historical stories with the recent events.

\section{f. Local Coherence}

Conditional, functional, and referential coherences have been searched in terms of the supposed knowledge structures. Propositions signify facts that are conditionally related, and facts are the referents of propositions. Conditional coherence is rarely used in specific narratives of the magazines. In the speeches or articles, there are ample samples of functional coherence which explain the former information with the second one. It gives not only an explanation but also a correction, an addition, or a contrast to the sentence. Referential relations can be 
observed in the topics by citing references on historical and recent events. It is generally systematic when cited to credible references.

\section{g. Lexical Style}

Word choices are usually related to the style of discourse. It may indicate the degree of formality, the affiliation between the audience, groups, and institutions, and especially the ideologies (Van Dijk, 2007: 150). For instance, the selection of 'terrorist' and 'freedom fighter' words depend on an implied expression within the associated value. In Daesh's publications, such opinioncontrolled lexical choices are plentiful and evident. "Victory, jannah, dignity, might, rights, leadership, brothers, single flag, one goal, one pavilion, faithful brotherhood, blessing, new era, master, honor, dignity, alert, awaken, jihad, triumph, two trenches, two camps, individual obligation" terms specifically signify the power and unity of the group. Lexically, "discipline, cut off, disgrace, neglect, dishonor, shake off, no third camp, humiliation, ignorant of" recalls the violent and brutal side of the narration. Opinion-controlled lexical choices can be observed in the appeals of the speeches, which are widely used as an ideologic routine. " $O$ America, $O$ allies of America, O Europeans, O crusaders, disbelievers, hypocrites" are the terms used for an intention to indicate and designate the enemy clearly. Conversely, "O soldiers of the Islamic State, O muwahhid, O you who believes, its soldiers, its sons, leaders" attract the attention of the group members by stressing a positive attitude towards them. It calls the targeted audience by using a lexical style for its ideological purpose, which totally divides the cognition into the black and white notions. Lexically, "against you, warned you, transgressed, oppressed, broken, defeated" words help to reveal an aggrieved and humiliated feeling of group members. Verbs, "shiver out, conquer, break, enslave, kill" recalls the violent side of the rhetoric used to attract the attention of the targeted audience. The lexical choices give important hints about the themes and the ideologic choices made by the narrator. "The Khalifah Ibrahim" term is used to signify the leader of Daesh in the opening parts of the speeches. The definition has a divine meaning which attributes celestial powers to him. We can trace the same 'nom de guerre' for the group leaders in the command chain. Besides, similar attributes are used which loads heavenly manners to the personalities of deceased members. Another intentional choice made by the narrator is the imperatives used successively to give orders to the members. Lexically, "Draw your swords", "Deal with the Rafidah", 
"Embitter their lives", "Be patient", "Do not hasten" imperatives help the narrator enforce the reader for the action. The sobriquets "Safawi Iraqi regime, Safawi Empire, factions of the tawaghit, pro-American Sahwah, Baathist Nusayriyyah, taghut Bashar, Shia Crescent, Mahdi of the Rafidah, Jewish Dajjal, apostate Rafidah, Safawi puppet, etc." are intentionally used to undermine the subjects and redefine them in the context of Daesh's narrative. The indicators are used to show an ideological choice which is made by the narrator as a determiner of the subject. Thus, the narrator aims to construct the discourse on undermining the enemy.

\section{h. Rhetoric and Effectiveness}

Discourse has standard strategies to inspire convincing processes. It may emphasize the real nature of events, build a relational parameter for facts or provide information on emotional dimensions (Van Dijk, 1988: 85). These strategies have been applied in almost all of the narratives in the magazines, with some exceptions. The events have been clearly identified in the speeches; nevertheless, the nature of these events is concealed behind the religious items and heroism, which were quite general and irrelevant, thus striving to harmonize mental representations of the narrator and the reader. Facts are not visible to biased readers. Yet, it touches the hearts and minds of a biased reader through its emotional dimension, which exploits his insufficient religious knowledge. The context of the speeches relies on the group member's past experiences of humiliation, specifically during the invasion of Iraq. Nonetheless, the glorification of Islamic history is an easier way of composing the texture of the story and a base for the mental preparation of members. There is a challenge against the enemy on its technical and military superiority through spirituality. The social and cultural nature of events and their cognition is different through time and place. Nonetheless, the narrator gives tangible information to make a connection with the historical event by quoting from religious references. It might seem like a strong bond at first glance unless a close study is not made. Rhetoric shows clear signs of the narrator's effort to rearrange the text by detaching it from its context by means of time, place, and occasion.

The marginalization process of the group members starts by preparation of their mental structures with the assistance of these propagative publications. The 
prejudiced group members are mentally prepared to believe the set of information if they are aligned with the common mental structure. There is considerable Islamic youth recruitment from the Western countries that were neglected and marginalized from the society as second-generation immigrants. Thus, the narrator uses this argument in an active way and utilizes the magazine effectively to give direct orders to the group members. These directions are elaborated especially in Rumiyah magazine as a reserved part for this purpose by explaining the action. Yet, the narrator does not detail the instruction for the members but gives the initiative to interpret and launch the action. The members are instrumentalized and inculcated to become a weapon. The distinctive feature of the violent actions is their attribution to sublime values. In this sense, there is no material obstacle that restricts a kind of fundamentalist movement which can escalate violence to its full potential. Besides other factors, the religious legitimacy of suicidal terror actions is established within the framework of the jihad concept. In fact, the ultimate discourse of salvation facilitates it for the member by playing a role in rationalizing the action. Daesh makes use of religion-based discourse effectively as a means of violence.

Even though Daesh challenges the enemy in religious aspects, it is an organized and politically motivated group since it uses every chance to convey the discourse of terror. It has been known that a great deal of Kurdish population in the region is Muslim. Daesh addresses them attentively not to confront through a nationalistic approach which will undermine the religious themes otherwise. So, the discoursal approach towards specific groups is meticulously designed. Another aspect of Daesh's rhetoric is its usage of emotional dimension for different regions and cultures. The preliminary parts in specific articles start with the glorification of related places and go on with related hadiths. With this adoration, the narrator intends to attach an emotional bond with the regional reader. These references strengthen the bonds of the different originated readers and gain veneration to the leadership. Besides, group members were seen as sanctified society members who merit the grace of God and superior to non-members. It might be an elitist way of thought for building barriers between the inner and outer group differences.

Sharing the same historical background works as an administrative apparatus and binding brick for a group of people with the intention of living together. The main aim is to build the joint capacity to accomplish public service and to pursue a 
shared vision of the future to form a community. Since Daesh iterates a borderless world in accordance with its aim, glorious victories of the ancient empires are the sole samples for the narrator's topicalization, which is frequently used in the narratives. The determination to achieve this main aim has been iterated in a historical and epic context. Agreements made between the colonial powers during First World War have been highlighted particularly to emphasize the artificial borders to be eliminated. Besides, Istanbul and Rome have been given as physical targets, which are described in the hadiths as cited to Prophet. Effective and fundamental objectives have been set in the narratives, which stand on strong referential to create a delusional reality for the group members. The effectiveness of the narrative increases since there is a strong correlation between the assertions and the given information. The justifications of the assertions do not rely on the quality of citing but the quantities in common.

Although the general composition of the population is mainly Muslim in the region, it has been deeply divided between the sects of the religion, which hinters the common sharing and cultural unity. This is the main vulnerability which is continuously abused by ex-colonials for today's religion-based administrative and sectarian organizations. Daesh's main objective is to establish a religion-based state inspired by the historical (prophetic) state. The historical contexts of the events are the main supportive device of this discourse which is linked to the recent events. Today's proxy wars are far more complex than the historical ones, which Syria is an excellent sample. According to Daesh, US, Russian, European, Arab, and Turkish intervention through the proxy organizations or militias made them some kind of close allies. Although there is harsh truth in this suggestion, the reality that come out in the mean time revealed that the countries supporting these proxies have different aims, which deviated from the intended mission. Lessons from the past of proxy wars confirm that there is no miraculous solution for a settlement. Nevertheless, the extension of these wars is exhausted for a country until a fundamental change can be found in the conflict's balance of power. As an inference, narratives are well designed to be effective on the group members in an effort to utilize the sectarian fragility of the region for the use of its ideological objectives. The efforts on propagating materials in the virtual world have utmost importance to achieve its regional and global aims. The rhetoric in these publications shows us a great deal of evidence in quantity regarding its aims. 
Nevertheless, the quality of these narratives is more prominent than the quantities, which may not gratify all the audience.

\section{Conclusion and Recommendations}

Daesh constructs its discourse on main narratives which rely on the religious themes which prefigure and integrate each other through its narrative. Themes are extracted from the references in a timeless manner which detach out of their context. Although the reference gives this narrative a legitimation, contextual analysis shows the background and the intention. Themes (manhaj, jihad, tawhid, jama'ah, hijrah, imamah, ummah, khalifah) are linked to form a cause and consequence cycle in the construction of this discourse. Themes can be interpreted from its context as; "Individuals must seek the truth on their own and organize themselves for a migration to the promised lands. The leader calls for unity, which will facilitate a holy war against the enemy. This war will assist establishing a state for the desired community." Besides, the analysis shows the characteristics of the discourse. Fictitious description of events, ideological separation in narratives, binary opposing themes in propositions, absence of gray zone in narratives, narratives adorned with celestial expressions, brutal imagery in visuals and photographs, vengeance of humiliation in narratives, motivation of group members in narratives, use of inner group jargon are the main specifications of a religiouslymotivated terror discourse used by Daesh. These specifications support and promote each other to form the structure of the discourse.

A discourse reflects the transmitter's standard of judgments which reproduces the power values of the transmitter and regenerates itself in every discourse. It is a consistent system and relates to inner and outer context. The discourse used in the magazines is in conformity with the essentials mentioned by Fairclough and Wodak (1997: 260). Because narratives in the magazines address the social problems in or out of the group, and power relations are dealt with more than expected. The narratives in magazines institute a society and culture which works ideologically and historically. Besides, they are interpretative and explanatory. Discourse is a form of social action which constitutes society and culture. Besides, it is historical and works ideologically. The unearthed specifications here intend to form a society and construct the culture. Additionally, it works ideologically by referring to the principal sources. The ideology works 
interdependently with the group and the society. It affects and is affected in both means and channels. Group (Daesh members and sympathizers) directly affects the events and incidents. Therefore, events are loaded with ideological context for the group to be interpreted in a socio-cultural environment. Society (the rest of the world) interprets events rather loaded with a biased understanding. The effect of propagative dissemination of the information for the society should not be underestimated in between these variables. In the center of the mentioned notions, religiously motivated terror discourse is affected by ideology and events, thus affecting the group and society.

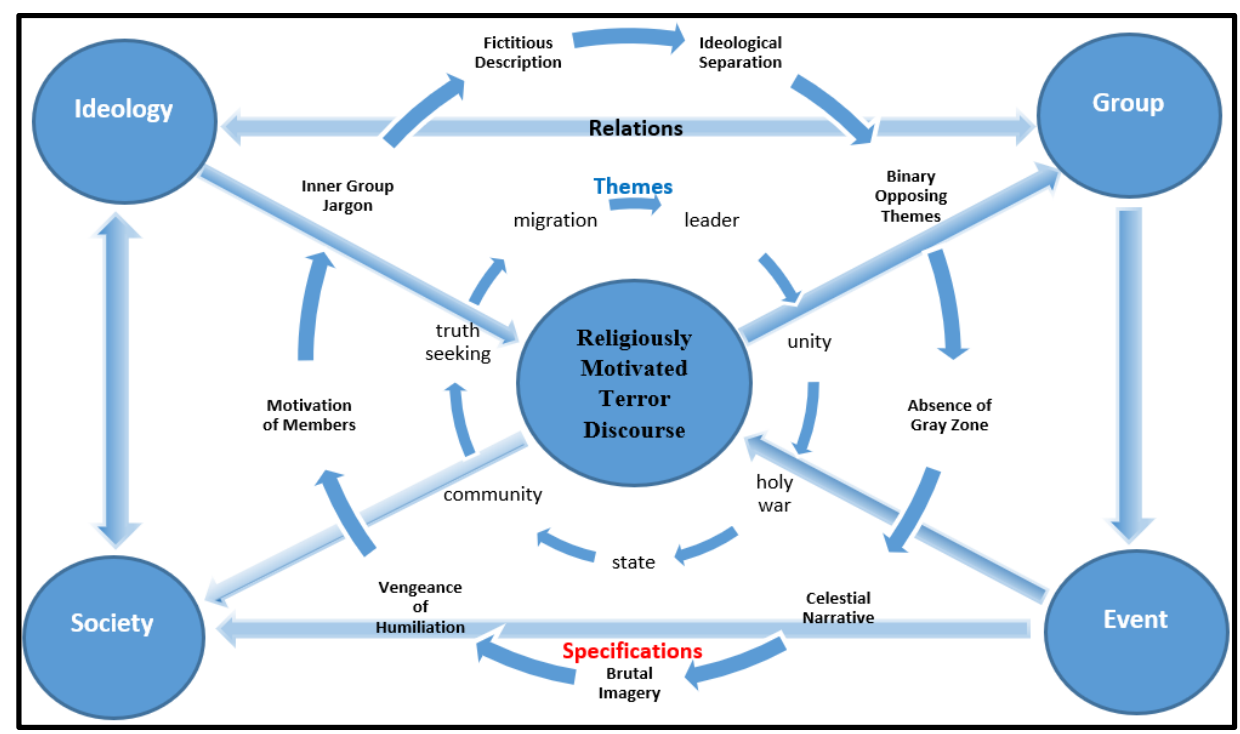

Figure 3. An Experimental Construction of Religiously Motivated Terror Discourse on Daesh Case (Kirazoluğu, 2020: 204).

The degradation of Daesh's territorial power incited them to give more emphasis on recruiting members by virtual means, which may help regain its strength. Dabiq and Rumiyah as propagative materials show the importance of its effectiveness in appealing to group members in theoretical and practical means. The number of the recruitments from the foreign countries shows its value although it lost qualified personnel on the field. The communicative side of the group gained importance which is an important aspect of the struggle for the executors. Perhaps the most important inference as some would say, is that Daesh has made a horrific abuse of the religion to legitimize its actions. The actual meanings of verses, 
hadiths, and religious concepts are being exploited. The conditions that formed its ideology and the contradictory aspects of the general provisions of Islam have to be analyzed in terms of developing a mutual discourse against radical religious identifications nurturing Daesh's ideology. This discourse should mainly be constructed by Islamic countries rather than the organizations subsidized by the Western countries.

\section{Genişletilmiş Özet}

\section{Giriş}

İletişim literatüründe terör söyleminin belirgin bir yeri olmakla birlikte, dini motifli terör söyleminin ayrıldığı noktalar mevcuttur. Motivasyon kaynağını dini söylem ve pratiklerden alan terör örgütleri ile mücadele etmek için söz konusu söylemin incelenmesine ihtiyaç vardır. Her ne kadar son dönemde fiziki olarak etkisini yitirse de Deaş terör örgütü ve onun insan kaynağ 1 üzerindeki etkisi merak konusu olmaya devam etmektedir. Deaş'ın söylemi ve kullandığı temalar bu bağlamda incelenmeye değer görülmektedir. Bu kapsamda yapılan çalışmada, Dini Motifli Terör Söylemi'nin Deaş terör örgütü örneğinde tanımlanması amaçlanmıştır. Araştırma esnasında, Deaş'ın çıkarmış olduğu Dabık ve Roma dergileri içerik ve tema analizine tabi tutulmuş, dergideki belirli yazılar ise Van Dijk'in söylem analizi tekniği ile incelenmiştir.

\section{Söylem Analizi}

Deaş'1n söylemini birbirini şekillendiren ve bütünleştiren temalar üzerine kurduğu, söylemin oluşumundaki temaların (hakikat arayışı, kutsal savaş, birlik, topluluk, göç, Müslüman toplum, devlet başkanı ve yönetim) bir sebep ve sonuç döngüsü içerisinde birbirine bağlantılı olduğu görülmüştür. Olayların kurgusal tasviri, anlatılarda ideolojik ayrılık ve gri bölgenin bulunmaması, önermelerde ikili karşıtlıklar, ilahi anlatım şekli, şiddetin görselleştirilmesi, aşağılanmaya ilişkin intikam söylemi, grup üyelerinin motivasyonu, grup içi jargonunun kullanımına yönelik temalar birbirlerini desteklemekte ve dini motifli terör söyleminin temel özelliklerini oluşturmaktadır. $\mathrm{Bu}$ söylem türü, tarihsel temelde bir toplum ve kültürün inşasını amaçlamaktadır. İdeoloji, ilişkili araç ve kanalları kullanarak, grubu ve toplumu karşılıklı olarak etkilemekte; toplum, önyargılı bir anlayışla ve ideolojik olarak yüklü bir şekilde olayları yorumlamakta; grup (Deaş üyeleri ve sempatizanlar) ise olayları doğrudan etkileyerek onları yorumlayabilmesi için 
ideolojik bağlama ihtiyaç duymaktadır. Oluşturulan söylem ise ideolojiye ve olaylara maruz kalmakta, böylece grubu ve toplumu etkilemektedir.

\section{Sonuc}

Yapılan incelemeden çıkarılan en önemli husus, Deaş'ın eylemlerini meşrulaştırmak için dini kavramları, zamansal, mekânsal ve olgusal anlamda bağlamından kopartarak gerçek anlamlarını istismar etmekte olduğudur. Böylece üyeleri ile sempatizanlanını etkileyebilmekte ve aidiyet duygusu oluşturabilmektedir. Deaş ve benzeri terör örgütleri ile mücadelede, karşıt söylemin gerçeklere dayalı bir şekilde, birbirlerini desteyen temalar halinde ve uygun hedef kitle üzerinde oluşturulması gerekmektedir. $\mathrm{Bu}$ söylemin ise Batılı ülkeler tarafından sübvanse edilen örgütler yerine, mücadelede ön safta olan ülkeler tarafından inşa edilmesi önem taşımaktadır.

\section{Bibliography}

\section{Books}

Aydinalp, H. (2011). İntihar Eylemleri Ekseninde Din ve Terör, Ankara: Birleşik Yayınevi.

Barthes, R. (1968). Elements of Semiolog. Hill and Wang.

Diamond, L. (2003). Islam and Democracy in the Middle East, Baltimore: The Johns Hopkins University Press.

Fairclough, N. and Wodak, R. (1997). Critical Discourse Analysis. In T. V. Dijk, Discourse Studies. A Multidisciplinary Introduction. Vol.2. Discourse As Social Interaction, 258-284, London: Sage.

Fernandez, Alberto M. (2015). Here to Stay and Growing: Combating Isis Propaganda Networks, Washington, Dc: Center For Middle East Policy At Brookings.

Juergensmeyer, M. (2000). Terror in the Mind of God: The Global Rise of Religious Violence, University of California Press.

Schmid, A. and De Graaf, J. (1982). Violence As Communication, Beverly Hills, Ca: Sage. 
Van Dijk, Teun A. (1988). News As Discourse, New Jersey: Lawrence Erlbaum Associates Inc. Publishers.

Van Dijk, Teun A. (2007). The Study Of Discourse: An Introduction, In T. V. Dijk, Discourse Studies. 5 Vols. Xix-Xiii, London: Sage.

Zelizer, B. (1995). Words against Images: Positioning Newswork in the Age of Photography, In H. Hardt, \& B. Brennen, Newsworkers: Towards A History of the Rank and File, 136, Minneapolis: University Of Minnesota Press.

\section{Articles}

Bennett, C. (2004). The Concept Of Violence, War and Jihad in Islam, Dialogue and Alliance, Dialogue and Alliance, Vol.18/1, 31-51.

Gates, S. and Podder, S. (2015). Social Media, Recruitment, Allegiance and The Islamic State, Perspectives on Terrorism, Vol.9/4, 107-116.

Kellner, D. (2006). 9/11, Spectacles of Terror and Media Manipulation, Critical Discourse Studies, Vol.1:1, 41-64.

Melki, J. and Jabado, M. (2016). Mediated Public Diplomacy of the Islamic State in Iraq and Syria: The Synergistic Use of Terrorism, Social Media and Branding, Media and Communication, Vol.4/2, 92-103.

Olufowote, J. and Matusitz, J. (2016).Visual Motifs in Islamist Terrorism: Applying Conceptual Metaphor Theory, Journal of Applied Security Research, Vol.11/1, 16-32.

Semati, M. and Szpunar, P.M. (2018). Isis Beyond The Spectacle: Communication Media, Networked Publics, Terrorism, Critical Studies in Media Communication, Vol 35/1, 1-7.

Vergani, M. and Bliuc, A.M. (2015). The Evolution Of The Isis' Language: A Quantitative Analysis of the Language of the First Year of Dabiq Magazine, Terrorismo E Società, Vol.2, 7-20.

Zeidan, D. (2003). A Comparative Study Selected Of Themes in Christian and Islamic Fundamentalist Discourses, Christian and Islamic Funbritish Journal Of Middle Eastem Studies, Vol.30/1, 43-80. 
Zelin, A.Y. (2015). Picture Or It Didn't Happen: A Snapshot of the Islamic State's Official Media Output, Perspectives on Terrorism, Vol.9/4, 85-97.

\section{Unpublished Works}

Kirazoluğu, O. (2020). Religiously Motivated Terror Discourse in Media: Daesh Case, Unpublished Doctoral Thesis, Girne American University Graduate School of Social and Applied Sciences, Girne.

\section{Web Page Article with no Author}

Beadle, S. (2017). How does the Internet facilitate radicalization? London: War Studies Department, King's College, London. Retrieved on 28.09.2020. https://d1wqtxts1xzle7.cloudfront.net/52630032.

Cosgrove, J. al-Chalabi, M. and Lee, S. (2014). Understanding the Threat: Explaining the Rise the Appeal of the Islamic State, John Hopkins University Applied Physics Labarotory, 100-109. Retrieved on 28.09.2020. https://www.start.umd.edu/pubs/START_ISIL_Lesson1_UnderstandingThe Threat.pdf.

Dabiq Magazine. Clarion Project. Retrieved on 02.10.2018. https://clarionproject.org/islamicstate-isis-isil-propaganda-magazine-dabiq.

Greene, K. (2015). ISIS: Trends in Terrorist Media and Propaganda. International Studies Capstone Research Papers, 3. Cedarville University. Retrieved on 28.09.2020.https://digitalcommons.cedarville.edu/international_studies_caps tones/3.

Liang, C. S. (2015). Cyber Jihad: Understanding and Countering Islamic State Propaganda, Geneva Center for Security Policy. International Studies Capstone Research Papers, 3. Cedarville University. Retrieved on 28.09.2020.https://www.jugendundmedien.ch/fileadmin/user_upload/3_Med ienkompetenz/Gegennarrative/Cyber_Jihad_Understanding_and_Countering _Islamic_State_Propaganda.pdf.

Nissen, T. E. (2014). Terror.com - IS's Social Media Warfare in Syria and Iraq, Military Studies Magazine, Royal Danish Defence College, Vol.2, 2-8. Retrieved on 15.05.2019. https://www.stratcomcoe.org/thomas-elkjernissen-terrorcom-iss-social-media-warfare-syria-and-iraq. 
Pellerin, C. (2016). Communicating Terror: An Analysis of ISIS Communication Strategy. Retrieved on 15.05.2019. https://www.sciencespo.fr/kuwaitprogram/wpcontent/uploads/2018/05/KSP_Paper_Award_Spring_2016_PEL LERIN_Clara.pdf.

Winter, C. (2015). The Virtual 'Caliphate': Understanding Islamic State's Propaganda Strategy, Quilliam. Retrieved on 15.05.2019. https://www.stratcomcoe.org/charlie-winter-virtual-caliphate-understandingislamic-states-propaganda-strategy. 